\title{
ВПЛИВ ЗМІНИ КЛІМАТУ НА ОСОБЛИВОСТІ МОРФОЛОГІЧНОГО АНАЛІЗУ ПРИ ОЦІНЦІ СТАНУ ПЕРЕЗИМІВЛІ ПШЕНИЦІ М'ЯКОЇ ОзИМОї
}

\author{
О. М. Кучеренко, Л. О. Хоменко, Г. М. Ковалишина, В. С. Кочмарський \\ Миронівський інститут пшениці імені В. М. Ремесла НААН
}

В умовах зміни клімату восени 2010-2012 рр. у пшениці м'якої озимої за оптимальних строків сівби відмічено прискорення розвитку рослин на I i II етапі органогенезу в середньому на 3-5 днів.

За роки досліджень виділено 2012 рік з аномально теплим осіннім періодом, коли довжина конуса наростання рослин сорту Подолянка за всіх строків сівби знаходилась в межах 0,43-0,30 мм, 3 якою пшениця озима зазвичай виходила б після перезимівлі. Довготривала, м'яка 3 частими відлигами зима 2012/13 р. призвела до збільшення приросту конусу наростання на 0,43-0,21 мм і рослини за строків сівби 15 і 25 вересня вийшли із зими вже на III етапі органогенезу.

У зв'язку зі змінами клімату і різною реакцією генотипів на підвищений температурний режим в осінньо-зимовий період слід звернути особливу увагу на строки сівби сортів пшениці м'якої озимої. Метод біологічного контролю озимих зернових культур можна використовувати при вивченні різних агротехнічних прийомів з метою виявлення оптимальних, а також для своєчасного проведення планомірних заходів під час формування елементів урожайності озимих культур.

Конус наростання, пшениия м'яка озима, зимостійкість, морфологічний аналіз, період, стан, сорт

Україна сьогодні є однією з провідних країн, що вирощує пшеницю м'яку озиму - основну культуру у виробництві хліба. Кліматичні чинники залишаються визначальними при формуванні іiі врожайності [1]. Нестабільність погоди і значні ії коливання до екстремумів ускладнили умови перезимівлі та вирощування культури [2].

У Лісостеповій зоні України часто спостерігаються пошкодження $\mathrm{i}$ навіть загибель озимих зернових культур унаслідок несприятливих умов перезимівлі. В основному загибель пшениці м'якої озимої обумовлена вимерзанням (зниження температури грунту на глибині залягання вузла кущіння до критичних температур), випріванням (часті відлиги і невисокі від’ємні температури на глибині залягання вузла кущіння), льодовою кір-

(C) О. М. Кучеренко, Л. О. Хоменко, Г. М. Ковалишина, В. С. Кочмарський. 2013. ISSN 0582-5075. Селекція і насінництво. 2013. Випуск 103. 
кою та іншими несприятливими факторами.

За останні роки значно змінились умови осіннього загартування озимих колосових, тому важливим $є$ проведення постійного контролю за станом загартування та проходження перезимівлі пшениці озимої [3].

У м'які зими, коли успішно перезимовує весь сортовий та селекційний матеріал культури, прямі підрахунки живих рослин в полі не відображають фактичної картини перезимівлі. Тому проведення оцінки стану посівів методом біологічного контролю за конусом наростання, залишається необхідним і актуальним.

Визначення етапів органогенезу і розробка експрес-методу біологічного контролю озимих протягом зимового періоду за станом конусу наростання [4] дозволили встановити ушкодження рослин озимих посівів від несприятливих умов перезимівлі: вимерзання, випрівання та ін., що знижують урожайність пшениці озимої [5].

Нестійкий характер погоди, який спостерігається в останні роки впродовж зимових періодів (2011/12 р., 2012/13 р.), зумовлюють продовження фізіологічних процесів в організмі рослин, у тому числі і ріст конусу наростання, що призводить до зниження морозо-зимостійкості пшениці м'якої озимої [6]. Тому селекціонери Миронівському інституті пшениці імені В. М. Ремесла НААН (МІП) приділяють велику увагу методу біологічного контролю при визначенні стану озимих зернових культур в період перезимівлі на всіх ланках селекційного процесу і на виробничих посівах.

Метою та завданням досліджень було встановлення впливу погодних умов осінньо-зимового періоду на довжину конуса наростання і реакцію на них сортів миронівської селекції при оцінці стану посівів пшениці м'якої озимої.

Дослідження проводили у лабораторії генетики і фізіології МІП в 2010-2013 рр. Для проведення досліджень використовували сорти пшениці м'якої озимої еталон-стандарт морозо-зимостійкості Крижинка [7], продуктивності - Подолянка та інші сорти миронівської селекції Світанок Миронівський, Миронівська 65, Сніжана.

Систематичний морфологічний аналіз за станом розвитку конусу наростання у пшениці мякої озимої проводили за методикою Куперман Ф. П. та ін. [8]. Для аналізу відбирали з поля проби по 25 типових рослин. Відібрані зразки поступово відтавали за температури 5-10 ${ }^{\circ} \mathrm{C}$. Відділяли рослини від грунту, промиваючи їх у воді.

Препарували конуси наростання за допомогою голки. Утримуючи рослину за корінці, голкою робили поздовжні розрізи головного стебла і послідовно видаляли верхні недорозвинуті листки, які покривали конус наростання. Довжину оголеного конусу наростання вимірювали за допомогою окуляр-мікрометра, що комплектується з бінокуляром МБС-2. За розробленою шкалою для довжини конусу наростання визначали етап органогенезу та ступінь пошкодження (п'ятибальна шкала ) [9]. Статистичний аналіз проводили за загальноприйнятою методикою [10].

Роки досліджень (2010-2013) характеризувались підвищеним темпе- 
ратурним режимом та короткою тривалістю зимового періоду за винятком (2012/13 р.) зимовий період у якому склав 116 днів. За середньобагаторічними даними для регіону, де розташований МІП, тривалість осінньозимового періоду складає 185 днів з зимовим - 108 днів [11]. За останні три роки вона зменшилась у середньому на 14 та 16 днів відповідно.

Пшениця озима у процесі росту та розвитку проходить два періоди. Протягом першого періоду росту рослин формуються головним чином вегетативні органи, які відповідають за основні функції в організмі - живлення, дихання, водообмін та ін. У другому - характерне формування генеративних органів (колосу, колосків, квіток і зернівок).

Найбільш важливим у озимини є перший період, що проходить восени, протягом якого рослини активно ростуть, проходять початкові етапи органогенезу у конусі наростання, де основні продуктивні органи знаходяться у зародковому стані, і відбувається накопичення цукрів, як захисних сполук перед зимівлею.

Конус наростання з зародковими листками послідовно формується на I етапі органогенезу з меристеми (ініціального поля) первинного пагона, 3 якого на наступних етапах відбувається процес його диференціації на різні за будовою тканини. У озимих культур є одна важлива особливість - зберігати восени вегетативний стан і не розвивати репродуктивні органи, що $\epsilon$ адаптивною ознакою, яка сприяє їх перезимівлі [12].

За сприятливих погодних умов (поступове зниження температурного режиму) протягом осіннього періоду відбувається зниження інтенсивності росту пшениці озимої, змінюються фізіологічні і біохімічні процеси в організмі рослини, які сприяють переходу їі до стану зимового спокою.

Однак за останні роки для осіннього періоду, особливо у листопаді та початку зими - грудні, характерні аномально високі перевищення норми не тільки середньодобової температури повітря, а і середньодекадної. Відхилення фактичної середньодекадної температури повітря від норми в осінній період 2010 р. становили $4,4^{\circ} \mathrm{C}$ (I декада жовтня ) - 9,0 $\mathrm{C}$ (II декада листопада) (рис. 1).

Аномально теплим був листопад 3 перевищенням середньомісячної температури повітря на $6,6^{\circ} \mathrm{C}$ у 2010 р., 2,6 $6^{\circ} \mathrm{C}-2012$ р., а у 2011/12 p. - грудень перша половина січня з перевищенням на $5,1^{\circ} \mathrm{C}$ (рис. 1).

Тривалість початкових етапів органогенезу залежала від погодних умов. Відомо, що волога і прохолодна погода сприяють збільшенню тривалості етапів, а жарка і суха, навпаки скороченню.

Так у рослин пшениці м'якої озимої за оптимальних строків сівби, через підвищений температурний режим осіннього періоду останніх років, в середньому до 3-5 днів прискорено проходження I етапу і рослини швидко переходили до диференціації основи конусу наростання на II етапі органогенезу.

Найбільш холодним місяцем в 2010/11 і 2011/12 р. був лютий. Середня температура повітря за місяць у 2012 р. склала мінус $11,1^{\circ} \mathrm{C}$, що на $6,6^{\circ} \mathrm{C}$ нижче норми. Мінімальна температура повітря у першій половині лютого знижувалась до $-25^{\circ} \mathrm{C}$ і нижче (шість діб). 


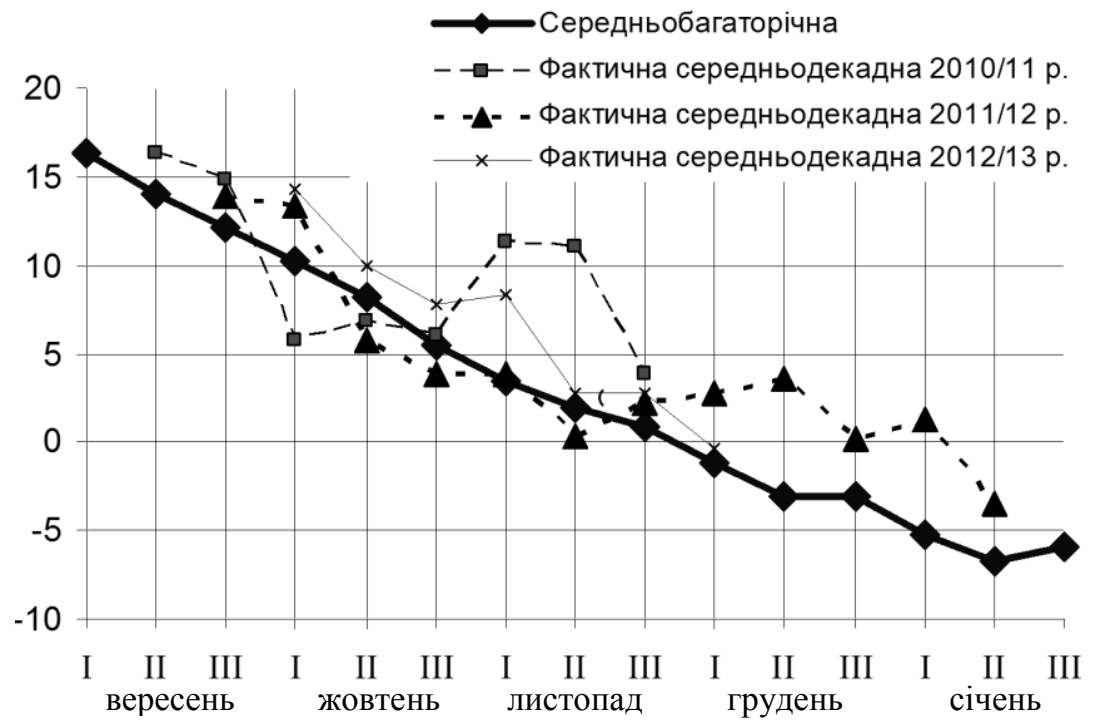

Рис. 1. Температурний режим осіннього періоду 2010-2012 pp.

Абсолютний мінімум $-30,7{ }^{\circ} \mathrm{C}$ відмічено 3 лютого, що найнижче за останні три роки. Висота снігового покриву на полях становила 10-20 см, що створювало надійний захист пшениці озимої від вимерзання. Найнижча мінімальна температура на глибині залягання вузла кущіння пшениці озимої становила $-13,5^{\circ} \mathrm{C}(2011$ р.), яка не перевищувала критичні температури вимерзання $-16-18^{\circ} \mathrm{C}$. Грунт у ці роки промерзав на глибину до $45 \mathrm{~cm}$.

Зима 2012/13 р. видалась довготривалою, м'якою (зі зниженням мінімальної температури повітря у грудні до $\left.-19,3{ }^{\circ} \mathrm{C}\right)$ з частими відлигами $\mathrm{i}$ снігопадами. Сніговий покрив залягав на полях переважно висотою 2025 см, що перешкоджало проникненню низьких температур повітря в грунт. У результаті мінімальна температура на глибині 3 см під снігом знижувалась до $-1,8^{\circ} \mathrm{C}$, а без нього - до $-3,9^{\circ} \mathrm{C}$. Грунт протягом зимового періоду максимально промерзав на глибину до 10-15 см.

Унаслідок наведених погодних умов пшениця озима (особливо у 2011/12 і 2012/13 рр.) лише призупиняла вегетацію 3 продовженням усіх фізіологічних і ростових процесів в організмі.

У МІП створено ряд сортів з високим рівнем морозо-зимостійкості. Один з перших - Миронівська 808, яка і до цього часу при проведенні оцінки селекційного матеріалу використовується як еталон-стандарт з підвищеним рівнем прояву ознаки. За оптимальних температурних умов осінньозимового періоду для рослин цього сорту наростання конусу наростання в кінці листопада повністю зупиняється і незначний приріст (до 0,15-0,20 мм) 
відбувається в другій половині зими [13].

На довжину і приріст конуса наростання також впливають строки сівби пшениці озимої. Вона повинна входити у зимовий період на II етапі органогенезу $з$ диференціацією основи конуса наростання. Як відмічали В. М. Ремесло, Ф. П. Куперман та ін. [14], посіви з оптимальним розміром конуса наростання $(0,25-0,35$ мм) мають найбільш високу зимостійкість і продуктивність. Ф. П. Куперман [4] вказувала, що від стану конуса наростання залежить життєздатність стебла, ріст і розвиток колосу та його продуктивність.

Стан конусу наростання визначали у сорту Подолянка (який використовують у МІП за стандарт продуктивності) за різних строків сівби - 15, 25 вересня і 5 жовтня. Проведений морфофізіологічний аналіз протягом осінньо-зимового періоду показав відмінності у довжині конуса наростання 3 залежності від погодних умов року і строків сівби (табл. 1).

Таблиця 1

Динаміка росту конусу наростання пшениці озимої сорту Подолянка упродовж осінньо-зимового періоду $(2010-2013$ рр.)

\begin{tabular}{|c|c|c|c|c|}
\hline \multirow{2}{*}{$\begin{array}{c}\text { Дата } \\
\text { посіву }\end{array}$} & \multicolumn{3}{|c|}{ Довжина конуса наростання, мм - етап органогенезу } & \multirow{2}{*}{$\begin{array}{c}\text { Приріст конуса } \\
\text { осінь -весна, } \\
\text { мм }\end{array}$} \\
\hline & $\begin{array}{l}\text { Осінь/дата } \\
\text { визначення }\end{array}$ & $\begin{array}{c}\text { Зима/дата } \\
\text { визначення }\end{array}$ & $\begin{array}{c}\text { Весна/дата } \\
\text { визначення } \\
\end{array}$ & \\
\hline & 10.11.2010p. & $7.12 .2010 \mathrm{p}$. & 22.03.2011p. & \\
\hline 15.09 & $0,31-\mathrm{II}$ & $0,35-\mathrm{II}$ & $0,43-\mathrm{II}$ & 0,12 \\
\hline 25.09 & $0,30-$ II & $0,29-$ II & $0,38-$ II & 0,08 \\
\hline 5.10 & 0,22 - I - кінець I & $\begin{array}{c}0,24- \\
\text { початок II - II }\end{array}$ & $0,31-$ II & 0,09 \\
\hline \multicolumn{4}{|c|}{ Середній } & 0,10 \\
\hline & 19.10.2011p. & 19.12.2011p. & 27.03.2012p. & \\
\hline 15.09 & $0,30-$ II & $0,44-$ II & $0,75-$ III & 0,45 \\
\hline 25.09 & $\begin{array}{c}0,22- \\
\text { кінець I - початок II }\end{array}$ & $0,32-\mathrm{II}$ & $0,49-\mathrm{II}$ & 0,27 \\
\hline 5.10 & $0,20-\mathrm{I}-\mathrm{K} \mathrm{I}$ & $\begin{array}{c}0,25- \\
\text { початок II - II }\end{array}$ & $0,39-$ II & 0,19 \\
\hline \multicolumn{4}{|c|}{ Середній } & $0,31^{*}$ \\
\hline & 23.10.2012 p. & $25.12 .2012 \mathrm{p}$ & 1.04.2013 p. & \\
\hline 15.09 & $0,43-$ II & $0,55-\mathrm{II}$ & $0,86-$ III & 0,43 \\
\hline 25.09 & $0,37-$ II & $0,48-$ II & $\begin{array}{c}0,64- \\
\text { початок III - III }\end{array}$ & 0,27 \\
\hline 5.10 & $0,30-\mathrm{II}$ & $0,44-$ II & 0,51 - II & 0,21 \\
\hline \multicolumn{4}{|c|}{ Середній } & $0,31^{*}$ \\
\hline
\end{tabular}

Примітка.

* середній приріст у 2011/12 р. і 2012/13 р. достовірно перевищує вказану величину 2010/11 p. (за t - критерієм Ст'юдента). 
У результаті досліджень впродовж останніх трьох років встановлено, що погодні умови конкретного року впливають на довжину конуса наростання пшениці озимої. За погодних умов осіннього періоду 2010/11 р. конус наростання сорту-стандарту Подолянка мав на всіх строках сівби приріст упродовж зими в межах 0,12-0,09 мм, у 2011/2012 - від 0,45 мм (І строк) до 0,19 мм (III строк). У 2012 році, через аномально теплий осінній період, довжина конуса наростання сорту знаходилась в межах 0,43-0,30 мм, 3 якою пшениця озима повинна була вийти 3 перезимівлі. Однак довготривала, м'яка 3 частими відлигами зима 2012/13 р., сприяла збільшенню його приросту на 0,43-0,21 мм і рослини за строків сівби 15 і 25 вересня вийшли 3 перезимівлі вже на III етапі органогенезу.

Результати проведення морфофізіологічного аналізу рослин сортів миронівської селекції за оптимальних строків сівби (15-20 вересня) під час перезимівлі 2012/13 р. наведено у таблиці 2.

Таблиця 2

Морфологічний стан рослин сортів миронівської селекції у кінці перезимівлі 2012/13 p.

\begin{tabular}{|l|c|c|c|}
\hline \multirow{2}{*}{ Сорт } & \multicolumn{2}{|c|}{$\begin{array}{c}\text { Довжина конуса наростання, } \\
\text { мм / етап органогенезу }\end{array}$} & $\begin{array}{c}\text { Приріст } \\
\text { за мі- } \\
\text { сяць, мм }\end{array}$ \\
\cline { 2 - 3 } Крижинка & $\mathbf{2 5 . 0 2 . 2 0 1 3} \mathbf{~ p . ~}$ & $\mathbf{2 8 . 0 3 . 2 0 1 3 ~ p . ~}$ & 0,08 \\
\hline $\begin{array}{l}\text { Світанок Миронів- } \\
\text { ський }\end{array}$ & 0,53 - II & $0,61-$ II - кінець II & 0,66 - \\
\hline початок III - III & $\begin{array}{c}0,77- \\
\text { початок III - III }\end{array}$ & 0,11 \\
\hline Миронівська 65 & $\mathbf{4 . 0 2 . 2 0 1 3 ~ p . ~}$ & $\mathbf{1 . 0 4 . 2 0 1 3 ~ p . ~}$ & \\
\hline Сніжана & $0,56-$ II & $0,73-$ III & 0,17 \\
\hline
\end{tabular}

У результаті частих відлиг у кінці зимового періоду у рослин досліджуваних сортів по-різному збільшувалася довжина конуса наростання, що свідчить про різну реакцію на відлиги. Найменшу довжину конуса наростання 0,61 мм (II етап органогенезу) з приростом 0,08 мм відмічено у сорту Крижинка і найбільшу 0,87 мм (III етап органогенезу) з приростом 0,27 мм у сорту Сніжана.

Таким чином, у зв'язку зі змінами клімату і різною реакцією генотипів на підвищений температурний режим в осінньо-зимовий період слід звернути особливу увагу на строки сівби сортів пшениці м'якої озимої.

Метод біологічного контролю озимих зернових культур можна використовувати при вивченні різних агротехнічних прийомів 3 метою виявлення оптимальних, а також для своєчасного проведення планомірних заходів під час формування елементів урожайності озимих культур. 
Висновки. 1. В умовах зміни клімату восени 2010-2012 pp. у пшениці м'якої озимої за оптимальних строків сівби відмічено прискорення розвитку рослин на I і II етапі органогенезу в середньому на 3-5 днів.

2. За роки досліджень виділено 2012 рік з аномально теплим осіннім періодом, коли довжина конуса наростання рослин сорту Подолянка за всіх строків сівби знаходилась в межах 0,43-0,30 мм, 3 якою пшениця озима зазвичай виходила б після перезимівлі. Довготривала, м'яка з частими відлигами зима 2012/13 р. призвела до збільшення приросту конусу наростання на 0,43-0,21 мм. і рослини за строків сівби 15 і 25 вересня вийшли із зими вже на III етапі органогенезу.

3. Метод біологічного контролю озимих зернових культур можна використовувати при вивченні різних агротехнічних прийомів з метою виявлення оптимальних строків сівби, а також для своєчасного проведення заходів в період формування урожайності озимих культур.

\section{Список використаних джерел}

1. Прокопенко А. Якщо взимку не буде екстремальних погодних умов, то цьогорічний врожай збіжжя перевершить торішній / А. Прокопенко // Зерно і хліб. - 2013.- № 1. - С. 6-8.

2. Рудник-Іващенко О. I. Особливості вирощування озимих культур за умов змін клімату / О. І. Рудник-Іващенко // Сортовивчення та охорона прав на сорти рослин. - 2012. - № 2. - С. 8-10.

3. Гаврилов C. В. Визначення життєздатності та прогноз перезимівлі озимих колосових культур / С. В. Гаврилов, П. О. Феоктістов, О. І. Нагуляк // Посібник українського хлібороба. - 2012. - Т.2. - С. 66-67.

4. Куперман Ф. М. Морфофизиология растений /Ф. М. Куперман. - М.: Высшая школа, 1977. - С. 43-71.

5. Куперман Ф. М. Методические указания по определению состояния озимых в осенне- зимне-весенний период по конусу нарастания / Ф. М. Куперман, В. Н. Моисейчик. - Л.: Гидрометеоиздат, 1977. - С. 28-69.

6. Розробити систему для оцінки елементів зимостійкості озимої пшениці. Визначити яровизаційний період зразків пшениці озимої на метаболічних фонах: Звіт про НДР (проміжний). / МІП імені В. М. Ремесла. № ДР 0111U002741. - Миронівка, 2006. - 22 с.

7. ДСТУ 4749:2007 Пшениця озима. Метод визначення морозостійкості сортів. - К.: Держспоживстандарт України, 2008. - 8 с.

8. Куперман Ф. М. Методические указания по определению потенциальной и реальной продуктивности пшеницы / Ф. М. Куперман, В. В. Мурашов, Л. В. Ананьева. - М, 1978. - С. 6-7.

9. Методические рекомендации по использованию морфофизиологического метода для оценки зимостойкости и устойчивости к оттепелям озимых культур / отв. ред. И. И. Василенко. - М., 1989. - 27 с. 
10. Доспехов Б. А. Методика полевого опыта / Б. А. Доспехов. - М.: Агропромиздат, $1985 .-351 \mathrm{c}$.

11. Агрометеорологический бюллетень многолетних данных по Мироновскому району Киевской области / под ред. Н. П. Скрипника. - К.: УКР УГКС, 1985. $-215 \mathrm{c}$.

12. Физиология сельскохозяйственных растений / отв. ред. П. А. Генкель. Изд. Московского унив., 1969. - Вып. 18. - С. 60-69.

13. Куперман Ф. М. О некоторых особенностях формирования и роста конусов нарастания у озимой пшеницы Мироновская 808 в зимне-весенний период / Ф. М. Куперман // Бюл. Мироновского НИИССП. - М.: Колос, 1974. -Вып.5. - С. 30-35.

14. Селекция и сортовая агротехника пшеницы интенсивного типа / [Ремесло В. Н., Куперман Ф. М., Животков Л. А. и др.]. - М.: Колос, 1982. C. 113-167. 